\title{
INFORMATION AND ANALYTICAL SUPPORT OF FINANCIAL CONTROLLING OF JOINT ACTIVITIES OF BUSINESS ENTITIES
}

\author{
Alla Dmytrenko*, D.Sc. (Economics), Associate Professor, \\ National University «Yuri Kondratyuk Poltava Polytechnic» \\ Larysa Marchenko, Chief Accountant \\ Poltava Regional Organization of the Professional Union of Certified Employees of the \\ Internal Affairs of Ukraine
}

* ORCID 0000-0003-3304-8652

(C) Dmytrenko A., 2020.

(C) Marchenko L., 2020.

Стаття отримана редакиією 15.08 .2020 p.

The article was received by editorial board on 15.08.2020

Introduction. Today, the issue of creating and implementing financial controlling in the work of business entities without which it is impossible to organize the circulation of management information about certain aspects of their financial activities, remains incomplete. The efficiency of building such a system of collecting, exchanging and processing data on economic activity is an objectively existing condition for ensuring the effectiveness of the implementation of financial controlling in the work of enterprises with ensuring its positive impact on the effectiveness of their operation. The research is directed on the decision of the certain problem question.

Analysis of recent researches and publications. Considerable attention was paid to the study of financial controlling in their writings: G.L. Vozniuk [3], A.I. Grigorash [1], A.A. Grigoriev A. [2], Zagorodny [3], G.P. Zadorozhnaya [4], A.A. Zorina [5], A.A. Kokovin A. S. [6], L.G. Lipic [7], Petrenko [8], G. Peach [9], S.V. Pryymak [10], I. Stefanyuk [11], O. Tereshchenko [12], T.S. Smovzhenko [3], D.M. Stashchuk [12], D.G. Savchuk [12], E. Sherm [9] and others. In addition, to improve the quality of information support for the implementation of joint activities between economic entities, it is necessary to consider in more detail the list of reporting documents, the use of which will improve the quality of financial data collection with their subsequent proper use. And to analyze and determine the basic requirements for controlling financial information, compliance with which will build an effective system of information circulation in the implementation of joint activities.

The purpose of the article is to deepen the scientific basis of the study of the origin and circulation of financial controlling information in joint activities, to consider the essence and determine the content of the category "information space of controlling information", which will identify the main centers of its production (primary departments, analytical services, external subs projects of information creation for management) and to single out specific features of different types of controlling information (external, internal, horizontal, vertical) and their role in the process of enterprise management. In addition, to offer the information space of controlling information to be considered as a single medium of data circulation on various components of development of a separate business entity, in which separate centers of production of such data operate and technical and relevant information systems of their analysis and transfer to management for management decisions.

Presentation of the basic material. In order to further explore the essence of the concept of information space, it is necessary to consider its properties and components that form a complete picture of the object of study.

The main structural components of the information space are information fields and information flows. An information field is a set of all information concentrated in space, regardless of its form and state, which is separate from both the object of reflection and the subject of perception. The movement of information in the information field is carried out through the physical connection between the recipient and the source of information that materializes in the information flow. The functioning of any management system requires the proper organization of information flow, i.e. its information flows. Information flows are the movement 
(movement) of information between people, employees of the department or between departments. The set of such movements is a system of information flows that make it possible to carry out any process.

The main purpose and purpose of information flows is to optimize management, and the smooth and gradual transition of information from the subsystem of the lower link to the subsystem of the higher link through the movement of such flows is accompanied by sequential accumulation, processing, grouping and selection.

To study the question of defining the information space of controlling information, first of all it is necessary to substantiate the essence of the concept of "controlling information". In the previous sections of the dissertation the main functions and tasks of financial controlling and its information support were investigated in detail, which gives an opportunity to outline its main components and develop an author's definition of this concept.

Information is a set of diverse data produced within individual departments of economic entities by certain specialists, which allows to obtain decisions on how to more efficiently and profitably organize the production of goods or services in an economic context. Accordingly, the combination of available knowledge and information becomes a strategic resource of the enterprise. Traditional paper media hinder the effective implementation of advanced management technologies such as financial controlling. In this context, the use of modern methods of collecting, processing, storing, analyzing and presenting information for the preparation of management decisions is one of the most important levers of business development. Information is also defined as a set of versatile signals that are produced by certain systems for further use in order to improve their functioning or other systems.

Thus, reasonable conclusions make it possible to define the concept of "financial controlling information" as a set of diverse data produced by individual structural units of economic entities, government agencies, other institutions and organizations and used in the preparation of reports for managers at various levels to adopt them correct management decisions. Financial controlling information is a complex concept because it characterizes the data generated within the management system of certain objects.

The next stage of the study is to determine the scope of the information space of controlling information. The definition of information space is considered as an object of management in accordance with modern conditions of development of industrial and economic relations. Therefore, we consider it necessary to expand the following category taking into account the peculiarities of the circulation of controlling information: "The information space of controlling information is a structured set of information objects that reflect the properties of objects, subsystems and processes of the joint venture and their methods" for management decisions, analysis, control and regulation of financial and economic activities of the joint venture.

Therefore, we can conclude that the system of information space of the enterprise is a separate system, but interconnected with the management system and the system of financial controlling.

The process of obtaining, processing and transmitting the necessary information to interested users is carried out within the financial controlling system, and the information that moves within it is the management financial information. Such information is formed within the financial controlling department according to accounting and analysis data.

However, a characteristic feature of the joint venture is that the information structure of joint activities is more complex, as it involves the formation of information space of individual participants in joint activities and information space and information flows between participants in joint activities.

The structure of links between information objects reflects the links between information processes in joint ventures, and the combination and coherence of information objects and links between them forms the information space of controlling information of joint ventures.

Given the study of the information space of the joint venture as a system that is a single whole with a set of interconnected and interacting components - information objects, but on a smaller scale within the external and internal environment, it is possible to develop a mechanism for forming information support with separation information flows by directions (login, processing in the system, logout) and allows you to schematically depict the impact of external information space on the activities of the joint venture, information processing in the management system, management decisions based on processed information, and output quality and reliable information to meet the information needs of external users.

Thus, the study of horizontal and vertical information flows of internal and external information indicates the complexity of the coherence of such flows between the subjects of joint activities, which requires the organization of such activities within the financial controlling of the joint venture.

The study of the concept and basic features of the information space and within its financial controlling system allowed to distinguish the composition of the subjects and objects of such a system with the definition of their information connections. 
The object of information space in the system of financial controlling is controlling information, which is a necessary and mandatory component of the information system in order to assess the situation, develop possible alternatives to management decisions and select the most appropriate for practical use and have the following properties and characteristics - should be consistent with the objectives and mission of the joint venture, the size and structural units of both the individual participants in the joint venture and the joint venture as a whole and their information needs regarding the quality and quantity of such information.

The issue of quality and usefulness of controlling information is closely related to the concept of structure and automation of information space and construction of information flows and links within the structural units of the joint venture as whole and individual participants in joint activities, as delays in obtaining the necessary information management decision.

The formation of a system of financial controlling cannot be imagined without the organization of an effective mechanism for the circulation of diverse information between departments and management of the joint venture. It is quite difficult to build models of production, exchange and analysis of data, taking into account some features of the functioning of various structural units of such enterprises, due to the specifics of their activities. However, without a productive system of management information management, it is impossible to create an effective financial controlling department. That is why the issues of organizational development of building an information support system within which the formation, circulation, exchange and analysis of controlling information between the subjects of joint activities and assessment of the amount of information support are quite relevant.

Compliance with the requirements for the quality and usefulness of controlling information, taking into account the organizational features of the information space of the joint venture and analysis of the components of the financial controlling system requires a study of effective system of collecting, processing and analyzing financial controlling information, joint venture. Therefore, the next issue that requires research is the question of justification for determining the required amount of controlling information depending on the organizational structure of the joint venture.

The optimal amount of financial information should be within the limits when the subjects of financial controlling have the opportunity to obtain sufficient information for its use in the framework of functional responsibilities, but not more than they can process within their own authority and qualification level. The criterion of optimality should also be applied to external users, as underestimation or too detailed disclosure of information reduces the level of effective decision-making.

Insufficient level of information support of the financial controlling system leads to an increase in the risk of making economically unreasonable management decisions, inefficient use of resources of the joint venture, an increase in the risk of joint activities, etc. Too much financial information can lead to the inability to process all information, reduce the likelihood of evaluating the most appropriate and reliable information, making erroneous management decisions. The financial controlling system requires only the information on the basis of which sound management decisions are formed.

Thus, the level of awareness of the enterprise and the ability to effectively and quickly evaluate the information obtained becomes one of the criteria for assessing the stability of the enterprise, the most important factor in survival in the fight against competitors.

The effectiveness of management decisions, and hence the stability of the joint venture as a whole, depends on the amount of financial information and its quality. Increased risk of joint ventures requires the management staff to form and use in management high-quality and reliable financial information in the amount of information capacity of the management system for processing and analysis.

Management of a modern enterprise, changes in consumer demand and market conditions require greater efficiency in ensuring the complexity of the information base for operational and strategic decisions and control over their implementation and depends on the quality and validity of decision-making. Therefore, the use of new information and network technologies requires their localization in the controlling system to increase the efficiency of management processes.

One of the main directions of improving the management system at business facilities is the introduction of information technology.

The introduction of the information system leads to positive changes in the activities of the enterprise and the emergence of new opportunities, among which are: the ability to take into account the complexity and diversity of products and services in planning and financial analysis; the ability to anticipate and meet the full range of customer service requirements; the ability to adequately assess the scale and complexity of markets; the ability to respond in a timely manner to changes in legislation; support for capital growth and human resource development; prompt response to market changes.

The simplest systems of automation of management accounting help to estimate the actual cost of the management product, the actual income, characteristics and indicators of material and financial flows; operational state of mutual settlements with suppliers / consumers; the real financial condition of the 
enterprise in terms of assets and liabilities, etc. If there is a planning contour of the system, it is possible to plan these indicators for future periods and constantly monitor the implementation of these plans.

The main source of controlling information is financial and management accounting information, and its analysis, evaluation and processing is carried out in other structural units of the management system of the joint venture.

Accounting is the main link in the integration of economic management information systems, as it forms the basis for statistical and tax reporting, tax calculation, operational management of economic and production activities of entrepreneurs to meet the needs of information users of different levels of government. However, under such conditions, the main direction of accounting development is the integration of different types of accounting into a single information system of economic accounting based on new information technologies.

Joint ventures prepare financial statements, providing information on the financial condition, results of operations and cash flows for the reporting period to a wide range of external and internal users.

All financial information goes to the financial controlling department for the purpose of its verification and further processing. Already within the specified department the application of the basic tools of financial controlling for processing of the received data, their detailed analysis according to requirements of the management, employees of other structural divisions, etc. is carried out. Aspects of strategic analysis of the positions of joint ventures in the financial market, assessment of its competitive advantages and the formation of general analytical reports on the current state of the joint venture are of particular importance and importance. The information obtained is passed to management for management decisions. The applied approach to the study of the nature and peculiarities of the circulation of financial controlling information does not mean that the head of any unit can not directly address the management of the joint venture with their own ideas and the necessary data to present them.

The introduction of mechanisms for automatic processing of controlling information depends on the management software. Information technologies of financial controlling are a system of components of hardware, technical and intellectual support, which are integrated with each other and interact in order to effectively automate controlling activities.

A special role among the components of information technology controlling is the information system as a set of certain tools, rules, methods, principles and algorithms for collecting, processing, storing and transmitting information, because software products provide organized hardware and create conditions for application and development of users' intellectual potential. In the system of financial controlling, information systems and technologies have become quite widespread as tools that increase the efficiency of the enterprise, but their implementation is quite a long, costly, time-consuming and risky process.

Currently, the domestic market presents a large number of information systems, the developers of which announce their wide range of capabilities to automate the management of joint ventures. Automation of financial controlling systems, which are developed and implemented on their own, allows you to create a software product that fully takes into account the specifics of business and information needs of its managers and controllers. However, this approach requires significant financial costs, which makes it virtually unacceptable for most domestic enterprises.

Ensuring a high level of quality of controlling information allows for the timely accumulation of useful analytical information, and on its basis - the development and evaluation of alternative management decisions with the choice of the most optimal and rational information-based solution in specific business conditions. Making management decisions at the final stage of a complex management process largely determines the level of its quality, ensures the competitiveness and efficiency of the business entity. It is "decision-making is the essence of the management process, its initial and most responsible stage, determines the level of productivity and efficiency of the entire system and management processes". Moreover, management decisions are the final stage of the management process and determine its outcome.

Thus, the quality of the management decision of the joint venture is a set of properties of the management decision taken by the management staff to achieve a common mission and goals and meet the information needs of external users and the interests of individual participants in the joint venture and the joint venture as a whole.

The study of the composition and content of qualitative characteristics of accounting information (financial reporting indicators) according to national and international standards indicates the existence of their basic composition, which is reflected in accounting standards (financial reporting), namely: clarity, relevance, reliability (true presentation), comparability (comparability). This basic (basic) composition of qualitative characteristics is enshrined in national accounting standards. The standards of materiality and timeliness are also present in international standards. However, the largest list includes the international standard of financial reporting for small and medium enterprises, which has 4 additional qualitative characteristics - prudence, the predominance of substance over form, completeness, cost-benefit ratio. 
Thus, the analysis of the documentation of the organization of joint activities and the formation of management and financial reporting of the joint venture allowed to identify areas for improvement of information and analytical support and to form an information space of controlling information of financial controlling of joint activities with subsequent effective use for management decisions by external and internal users.

Thus, today the forms of financial reporting take into account the requirements of international financial reporting standards, but there are still a large number of uncoordinated issues on the harmonization of methods of compiling national forms of financial reporting with international ones. Forms of financial statements do not yet differ from the minimum set of items as required by International Financial Reporting Standards. The main advantage of the reform is the alternative of the company's choice of reporting method (direct or indirect - for the Statement of Cash Flows), the method of displaying items (only at residual value or at residual and original cost), selection and inclusion of individual items from the general list, proposed by legislators.

Thus, the harmonization of accounting and methods of preparation of financial statements of Ukraine with international standards contributes to the clarification of current provisions (standards) of accounting in Ukraine.

Conclusions. Thus, the essence, properties of the information space of the controlling information of the enterprises of joint activity as the object of management are considered. Proposals for defining the information space of controlling information as a structured set of information objects and methods of their organization have shown that the level of its structure significantly affects effective management decisions, and external and internal factors affect the volume, quality and usefulness of controlling information and information flows and links between the structural units of the joint venture.

Insufficient attention on the part of management staff to the formation of a rational structure of financial controlling of joint activities leads to the fact that the use of financial, technical, personnel, organizational, intangible support and obtaining quality and timely information does not give the expected results. The management staff uses more resources to create computer management systems, training of employees of the financial controlling service, but does not pay attention to the study of information needs of users and their relationship with the amount of information produced and provided.

To ensure the maximum efficiency of controlling activities at the joint venture, it is advisable to choose those information systems that best meet the information needs of managers and controllers.

Thus, the study of the quality and usefulness of controlling information and methods of their evaluation is important and necessary from the standpoint of improving the information space of controlling information and improving the information flows of the management system of the joint venture.

\section{REFERENCES:}

1. Hryhorash A.I. Controlling as a modern enterprise management system. Actual problems of Economics. 2010. No 11 (113). P. 96-107.

2. Grigoriev A.A. Theoretical foundations of controlling. URL: http://www.nbuv.gov.ua/portal/Soc_gum/aprer/2009_5_2/33.pdf

3. Zahorodnyi A.H., Vozniuk H.L., Smovzhenko T.S. Financial dictionary. Lviv: "Knowledge", 2002. 566 p.7. Zahorodnyi A.H., Vozniuk H.L., Smovzhenko T.S. Financial dictionary. Lviv: "Knowledge", 2002. $566 \mathrm{p}$.

4. Zadorozhnaya G.P. Controlling as a concept of management of financial-gospodarica the activity of the enterprise. Vestnik. 2010. No 1 (11). P. 46-50.

5. Zorina A.A. the Problems of interpretation of the controlling. Statistics of Ukraine. 2011. No. 1. P. $40-44$.

6. Kokovin A.A. The need for financial controlling as a system of effective management of the enterprise activities railway transport. Journal of Transport Economics and Industry. 2012. No. 38. P. 196199.

7. Lipych L.H. Controlling in the crisis management system. [Electronic resource]. Mode of access: http://www.nbuv.gov.ua/portal/natural/Vnulp/Menegment/2012_722/72.pdf

8. Petrenko S.N. Controlling: manual. Kyiv: Nika-The Center, Elga, 2004. 328 p.

9. Pich G., Sherm E. Clarification of the content of controlling as a function of control and its support. Problems of Theory and Practice of Control. 2001. No 3. P. 102-107.

10. Pryimak S.V. Diagnosis of the financial state of the enterprise in the controlling system: author. diss. for the sciences. degree of cand. econom. sciences: special. 08.00.08. - Mode of access: http://www.irbis-nbuv.gov.ua/cgi-bin/irbis64r_81/cgiirbis_64.exe 
11. Stefaniuk I.B. Concepts, essence and causes of controlling. Finance of Ukraine. 2005. No 2. P. $146-153$.

12. Tereshchenko O.O., Stashchuk D.M., Savchuk D.H. Current status and prospects of development of financial controlling (to the results of Ukrainian-Russian round table). Finance of Ukraine. 2011. No 2. P. $117-126$.

\section{УДК 658.012 .32}

JEL: M1

Дмитренко Алла Василівна, доктор економічних наук, доцент. Національний університет «Полтавська політехніка імені Юрія Кондратюка». Марченко Лариса Юріївна, головний бухгалтер Полтавської обласної організації професійної спілки атестованих працівників органів внутрішніх справ України. Інформаційно-аналітичне забезпечення фінансового контролінгу спільної діяльності суб'єктів бізнесу. Проаналізовано особливості формування та обігу контролінгової фінансової інформації, визначено ऑiі сутність, обгрунтовано особливості функціонування інформаційного простору спільної діяльності та розроблено заходи поліпшення обігу управлінських даних між учасниками спільної діяльності й окремими центрами їх продукування в межах діючої господарської структури. Для поглиблення наукових засад дослідження особливостей виникнення та обігу фінансової контролінгової інформації при здійсненні спільної діяльності розглянуто сутність та визначено зміст категорії «інформаційний простір контролінгової інформації», що дало змогу виявити основні центри їі продукування й виокремити специфічні риси різних типів контролінгової інформації та їхню роль у процесі управління підприємством. Запропоновано інформаційний простір контролінгової інформації розглядати як єдине середовище обігу даних про різні складові розвитку окремого суб'єкта господарювання, у якому здійснюють свою діяльність окремі центри продукування таких даних і функціонують технічні й відповідні інформаційні системи їх аналізу та передачі керівництву для прийняття управлінських рішень. Встановлено, що розвиток системи фінансового контролінгу спільної діяльності безпосередньо пов'язаний 3 ефективністю функціонування механізмів обігу контролінгової фінансової інформації у процесі ії функціонування, що обгрунтувало доцільність поглиблення теоретико-методологічних засад забезпечення належних умов для акумуляції та аналізу такого виду даних. У зв'язку із цим було уточнено сутність дефініцій «інформаційний простір контролінгової інформації» та «контролінгова фінансова інформація». Розроблено рекомендації щодо підвищення якості інформаційного забезпечення здійснення спільної діяльності, що реалізовано за допомогою розробки сукупності документів. Визначено, що розширення переліку звітних документів, автоматизація їх формування дають змогу збільшити доступність даних про різні аспекти здійснення спільної діяльності й сприяють прийняттю більш виважених управлінських рішень для її подальшого розвитку.

Ключові слова: контролінг, фінансовий контролінг, планування, контроль, управління, спільне підприємство, спільна діяльність.

\section{UDC 658.012.32}

JEL: M1

Dmytrenko A.V., D.Sc. (Economics), Associate Professor. National University «Yuri Kondratyuk Poltava Polytechnic». Marchenko L.Yu., Chief Accountant. Poltava Regional Organization of the Professional Union of Certified Employees of the Internal Affairs of Ukraine. Information and Analytical Support of Financial Controlling of Joint Activities of Business Entities. The peculiarities of the formation and circulation of controlling financial information are analyzed, its essence is determined, the peculiarities of the information space functioning of joint activity are substantiated and measures to improve the circulation of management data between participants of joint activity and separate centers of their production within the current economic structure are developed. To deepen the scientific basis of the study of the origin and circulation of financial controlling information in joint activities considered the essence and content of the category "information space of controlling information", which allowed to identify the main centers of its production and identify specific features of different types of controlling information and their role in the process enterprise management. It is proposed to consider the information space of controlling information as a single medium of data circulation on various components of development of a separate business entity.

Key words: controlling, financial control, planning, control, management, joint venture, joint activity. 